\title{
Correction
}

\section{Correction to: Characterization of polyethylene terephthalate wastes/Acrylonitril-Butadiene styrene (PETW/ABS) composites with applications of artificial neural networks}

\author{
Fahimeh Derakhshanfard $^{1}$ (iD $\cdot$ Amir Mehralizadeh $^{1}$
}

Published online: 23 October 2020

(c) Springer Nature Switzerland AG 2020

\section{Correction to: SN Applied Sciences (2020) 2:1730 \\ https://doi.org/10.1007/s42452-020-03546-9}

There was a typo in the first author's name in the initial online publication. The original article has been corrected.

Publisher's Note Springer Nature remains neutral with regard to jurisdictional claims in published maps and institutional affiliations.

The original article can be found online at https://doi.org/10.1007/s42452-020-03546-9.

Fahimeh Derakhshanfard, f.dfard@gmail.com | 'Department of Chemical Engineering, Islamic Azad University Ahar Branch, Ahar, Iran. 